\title{
Official call
}

To the officers and members of the American Osteopathic Association:

You are hereby notified that the annual business meetings of the American Osteopathic Association will be held July 16 through 21 at the Opryland Hotel in Nashville, Tenn.

The opening session of the annual meeting of the Board of Trustees will be held at 8:30 AM on Tuesday, July 16.

The House of Delegates will convene for the annual business session of the Association at 10:30 AM on Friday, July 19. All meetings of the House of Delegates will be held at the Opryland.
The Committee on Credentials will register delegates and alternate delegates beginning at 8 AM on Friday, July 19. The House will conclude its session on Sunday, July 21.

By June 16, the secretary of each divisional society and each practice affiliate must certify to the Executive Director of the American Osteopathic Association a list of the names and addresses of delegates and alternate delegates.

\section{Howard L. Neer, DO, President \\ T. Eugene Zachary, DO, Speaker of the House}

\section{Proposed Amendment to the Constitution of the American Osteopathic Association}

At its July 1995 Annual Meeting, the House of Delegates approved the following proposed amendment to the AOA Constitution. In accordance with AOA basic documents, the amendments are to be printed in the JOURNAL OF THE AMERICAN OSTEOPATHIC AsSOCIATION prior to the meeting at which they are to be acted upon (July 1996).

\section{CONSTITUTION}

Article VIII-Board of Trustees and Executive Committee,

Section 1-Board of Trustees

(new material in brackets/italics)

The Board of Trustees of this Association shall consist of the President, President-elect, the Past Presidents for the preceding two years, First Vice President, Second Vice President, Third Vice President and of eighteen other members; six of whom shall be elected annually by the House of Delegates to serve for three years. With the exception of the President, President-elect and the Past Presidents for the preceding two years, the terms of office of Trustees shall be limited to [not more than] twelve (12) years, with the exception that a Trustee may complete the term in which twelve (12) years or more of service is completed.

Explanatory statement: This proposed Amendment imposes a limitation of twelve years total, not just consecutive years. Any Trustee who has served for twelve or more years will not be eligible for election as a Trustee or Vice President but shall be eligible to become President-elect. Any Trustee who has a total of less than twelve years (e.g., ten years) may be elected to a three-year term and may serve out that term, even though it may exceed twelve years. 